\title{
Promotional practices in mission and vision statements of corporate companies: A systemic functional linguistic analysis
}

\author{
Iman Aib* | Wasima Shehzad | Sadia Irshad \\ Department of English, Air University, Islamabad, Pakistan. \\ *Corresponding Author Emails: iman.aib93@gmail.com
}

\begin{abstract}
Promotional strategies have become discursive practices in corporate companies' mission and vision statements. However, less focus was given to the role of grammar in shaping this text type as part of promotional discourse. Systemic Functional Linguistics (SFL) is arguably the most definite and certain linguistic analysis as a meaning-making resource. Hence, the purpose of this study was to use transitivity grammar theory in SFL to analyse the use of experiential processes in enacting promotional rhetorical moves. Following purposive sampling, mission and vision statements of hundred international companies, which were ranked by current market capitalization, were selected. Using textual analysis, we applied transitivity grammar theory to manually analyse promotional rhetorical moves. The results were quantified and presented in tabulation form. The findings revealed that mental and relational processes are favoured grammatical patterns used by corporate firms to write mission statements that focus on building public image and establish self-concept. The findings of this research can prove helpful for other corporate companies to use similar grammatical patterns to develop mission and vision statements.
\end{abstract}

Article History

Received:

April 3, 2021

Last Revised:

June 18, 2021

Accepted:

June 24, 2021

Published:

June 30, 2021

Keywords: mission statements, systemic functional linguistics, genre, promotional genre, genre analysis, transitivity theory, corporate discourse, vision statements.

\section{How to Cite:}

Aib, I., Shehzad, W. \& Irshad, S. (2021). Promotional practices in mission and vision statements of corporate companies: A systemic functional linguistic analysis. Liberal Arts and Social Sciences International Journal (LASSIJ), 5(1), 630-647. https://doi.org/10.47264/idea.lassij/5.1.41

Publisher's Note:

IDEA PUBLISHERS (IDEA Journals Group) stands neutral with regard to the jurisdictional claims in the published maps and the institutional affiliations.

Copyright: () 2021 The Author(s), published by IDEA PUBLISHERS (IDEA Journals Group). This is an Open Access article published under the Creative Commons Attribution-NonCommercial 4.0 International License (http://creativecommons.org/licenses/by-nc/4.0/) 


\section{Introduction}

The increasing demand of English for Specific Purposes (ESP) in the applied linguistics context has strengthened the role of Systemic Functional Linguistics (SFL) to define the linguistic characteristics of text types (Bateman, 2008; Bhatia, 1983; 2004; Swales, 1990). One aspect of SFL theory deals with transitivity system, which centres on how people construe reality and convey experiences by applying a wide range of syntactic structures (Halliday \& Matthiessen, 2004). This approach is relevant to the discourse of mission-writing in professional practices. Mission and vision statement are generally identified as the most important steps to strategic planning; in the corporate sector, mission and vision statements can play a strategic role in guaranteeing the performance of the company (Hongwei, 2012; Koller, 2009; Pearce \&David, 1987). Due to the enormity of this genre, the mission statements are continuously being researched regardless of being labelled as ambiguous and inconsistent in sustaining their communicative purposes (Boerema, 2006; Hayden, 2012; Drucker, 1974; Rozycki, 2004; Swales \& Rogers, 1995). Although previous studies used content analysis as a method to explore the function of this genre (Bittencourt \& Willetts, 2018; Breznik \& Law, 2019; Hafferty et al., 2019; Velcoff \& Ferrari, 2006), transitivity theory of SFL was less used as a method of analysis. Therefore, analysing the grammatical clauses of mission and vision statements is deemed necessary to understand the linguistic nature and functional role of mission-writing in corporate discourse.

Although the discourse community of planning and management has remained consistent in monitoring how organisations develop mission statements, the influence of globalization and international marketization makes it difficult to study the same (Rego et al., 2015). The inception of globalization instigated an inevitable competition between both nations and organisations, which has resulted in a drastic shift in the communicative purpose of mission and vision statements (David \& David, 2014; Goertzen \& Kristjanson, 2007). From substantiating purpose to informing strategic planning, this text type has become a prototypical example of brandization and marketing. Mission statements act as the basis for an organisation's priorities, strategies, and plans; in essence, these statements announce the existential purpose of organisations (Bartkuset al., 2006; Christensen \& Askegaard, 2001; Mason \& Mason, 2012). According to Pearce and David (1987), the purpose of mission and vision statement should be to develop a unique purpose of the company and to inform a targeted audience about the tasks it executes and why it needs to execute them. Within the corporate context, mission statements simultaneously define the beliefs and values behind a company's profile while emphasising a set of products or services it offers, typically at a competitive price. Some researchers have opined that it is the "most visible and public part of a strategic plan" (Pearce \& David, 1987, p. 109).

Mission statements seemingly carry the pulse of corporate realities, no matter the type of organisation; all kinds of institutions like private schools, healthcare facilities, and financial firms adhere to this rationale (David \& David, 2014; Fairclough, 1993). However, to understand how promotional rhetorical moves are favoured by international corporate companies to write mission statements, there is a need to explore the transitivity system of this genre. The purpose of using SFL was to provide a comprehensive, goal-oriented approach for the linguistic description of mission statements used by international companies. Hence, by analysing the system of transitivity patterns of mission and vision statements, the objective was to identify how promotional rhetoric was enacted through transitivity patterns. 
Following a textual analysis, hundred international corporate companies' mission and vision statements were manually analysed using transitivity theory of grammar to explore promotional rhetoric enacted through experiential processes. To understand the communicative purposes achieved through lexico-grammatical features, this research revealed the most frequent experiential processes associated with each rhetorical move of mission and vision statements. The interplay of rhetorical moves and their surface-level grammatical structures allows a more meaningful description on the use of specific lexico-grammatical resources and how they develop meanings. With this purpose, answers were sought to the questions: a) What are the transitivity patterns of experiential meanings used in mission statements of corporate firms? $b$ ) What rhetorical moves are reflected by the transitivity patterns of experiential meanings in mission statements of corporate firms?

Section 2 critically evaluates articles relevant to this research and establishes the niche of this study; section 3 situates the theoretical framework and section 4 outlines materials and methods used to carry this research; section 5presents quantitative and qualitative analyses of experiential processes. The results revealed the grammatical patterns of transitivity used to enact promotional rhetoric in the selected mission and vision statements and demonstrated the value of employing SFL theory such as transitivity system, which allows for a thicker description of language as a meaning-making resource. Finally, section 6outlines the conclusion of the findings and addresses the implications of this analysis.

\section{Literature review}

This research has attempted to explore how lexico-grammatical resources enact promotional rhetoric in mission statements of international companies. For this purpose, this research has relied on SFL as a grammar theory for the analysis. Mainly, the application of SFL theory created a new linguistic field to analyse how discourse communities constructed or construed meaning from texts (Eggins, 2004; Halliday \& Matthiessen, 2004; Li, 2010; Martin \& White, 2007). SFL theory has largely dealt with how words were employed in a specific cultural or social context to enact communicative purposes (Halliday, 1978). This notion was also emphasized by Hasan (2009), who stated that contextual choices activate semantic choices, which further activate the lexico-grammatical choices. Although genre analysis focuses on macro-structures of the text (Bhatia, 2004; Swales, 1990), without studying text-internal properties, a comprehensive understanding of the genre is limited (Derewianka, 1990; Ravelli, 2000). Since the purpose of SFL is to analyse and explore the linguistic functions of text production, genre analysis and SFL are inter-connected in which the understanding of the genre is partially realized through grammar.

Arguably, the analysis of the lexico-grammatical resources reveals that the communicative purposes of promotional genres are partially influenced by the linguistic resources used to shape them (Askehave, 2007; Pho, 2008). Promotional genre is one in which prototypical texts comprise similar communicative purposes such as promoting products or services. Sometimes, the promotional purpose may be to market an 'idea' instead of products or services. As has been previously reported in the literature, mission statements carry corporate purposes as companies strive to build their public image and reinforce their self-concept (David et al., 2011; Khalifa, 2011). Prior research suggests that mission statements were used by companies to build a public image by aligning their philosophies and values (Campbell et al., 1991). Based on this notion, there exists a considerable body of literature which analysed the mission statements from a similar perspective. 
For instance, Yurtseven (2003) carried a survey on five-star hotels' mission statements (as cited in Ozdem, 2011). He found that $52 \%$ of these mission statements focus on product and service promotion; $48 \%$ to state organization's philosophy; 647 to emphasize customers; $44 \%$ to reflect on environmental-social responsibility; and $56 \%$ to adhere to high quality and innovation. Henceforth, mission statements can be characterized as a sub-category of the promotional genre. A recent study by Lin et al. (2018) similarly concluded that the primary purpose of mission statements was to emphasize the company's qualities and values to attract customer. Drawing on seventy-nine passenger airlines, they found the most recurrent mission statement components focusing on the product or service, customers, location, and safety to ensure confidence among consumers. Ostensibly, this research suggests that promoting service or product is an important part of writing mission statements, which is also a recurrent rhetorical move in promotional genre.

Over time, an extensive literature has developed on the need to address the role of mission statements in corporate setting. Prior research suggested that mission statements help companies distinguish themselves as different from other corporate personalities (Kemp \& Dwyer, 2003). Authors like Holland and Nichele (2016) have drawn further development of this genre. They devised an ideological content analysis (FDM) and examined the mission statements of Coca-Cola and Pepsico. Their analysis portrayed mission statements as corporate manifestos to provide statements of vision, value, and strategy. Koller (2009) similarly defined companies as social agents who maximize profit and shareholders' value. She opined that mission statements had become more like 'corporate brand' which are ideally suited to produce branding propositions to potential customers. This type of communication is characteristically market-oriented, which is understood as the type of communication in which the company reinforces itself through positive image (Christensen \& Askegaard, 2001). Similarly, Allison (2017) studied seven hundred and ninety-eight vision and mission statements of corporate firms through text analysis to develop natural language taxonomy for vision and mission statements. He found that the common top ten words that categorized this genre were 'customer', 'deliver', 'service', 'shareholder', 'value', 'product', 'employee', 'meet', 'solution' and 'partner' asserting that vision and mission statements are used to deliver products or services, which was also identified as a recurrent rhetorical move of this genre.

In short, the literature pertaining to the genre of mission statements strongly suggests that this text type is a prototypical example of promotional genre. However, prior studies have almost exclusively focused on content analysis to examine mission statements. A recent study by Ahmad and Masroor (2020) brought a new perspective to mission statements. They explored the generic patterns of mission and vision statements of universities and revealed few existing promotional rhetorical moves such as "Expressing Institutional Aspirations" (p. 175). Although this study is a new contribution to the genre of mission statements, it has given little emphasis to lexico-grammatical resources. Because promotional rhetoric is ostensibly left implicit in the text and can only be revealed by unravelling the tactics of promotion employed (Bhatia, 2004), it requires the genre analyst to dissect the grammatical resources of the text as well.

Arguably, Fairclough's (1993) linguistic analysis of universities' mission statements remains a valid contribution to SFL. He opined that universities use pre-modifiers and modal verbs in their mission statements to advertise their services. Bittencourt and Willetts (2018) similarly explored international universities' mission statements and concluded that an ideological perception of internationalism drove their motives. However, their research work was based on the content analysis as a method of inquiry. Despite the increasing appearance of the 
promotional rhetoric in mission statements, little research has been done to explore how transitivity patterns of grammar enact such purposes. We suggest that a broader analytic perspective is required for a fuller understanding of the functions of the promotional rhetoric in the mission statements.

SFL is arguably the most definite and certain linguistic analysis in dealing with meanings as it focuses on correlating language and context. SFL has proved to be a useful beginning point for the analysis of mission statements. For instance, the following studies were conducted on SFL. A recent study by Benelhadj (2019) examined academic genre by bringing prepositional phrase complexity to focus. The researcher found simple prepositional phrases (774 in frequency) as more common and recurrent than complex prepositional phrases (32 in frequency). The most common prepositional phrases were composed of the structure 'prep+noun+prep' such as 'in addition to'. Impersonality in research articles - often expressed through transitivity structures - was analysed by Martinez (2001). Using the SFL approach, the researcher selected twentyone experimental studies from physics, biology and sociology. Martinez (2001) found material processes to be more frequent than relational. However, these processes were used variably in different sections of research articles. For instance, in results sections, authors tend to imply relational processes to maintain distance from the text, whereas mental processes were used to mitigate claims. A transitivity analysis of rhetorical moves in Thai and international dental research abstracts was conducted by Vathanalaoha and Tangkiengsirisin (2018) using a corpusbased method that compared tonal styles in rhetorical moves. Selecting one-twenty dental articles, they used Halliday (1994) SFL approach and Thompson's (2000) verbal choices of transitivity. The researchers found that verbal and existential processes were mostly used in methodological sections, whereas verbal processes were most frequently used in discussion sections. These studies have made seminal contributions to SFL theory by validating the potential role of grammar in shaping text types.

In general, it appears that majority of prior research based on genre analysis has applied SFL perspective to analyse text types. Although previous research provides insightful categorization of mission statements as a prototypical example of promotional genre, employing SFL theory to analyse promotional rhetoric has remained limited. We suggest that combining move analysis with SFL perspective might be a useful way to address mission statements that would also be useful for companies who wish to write persuasive mission statements. Using SFL theory to analyse mission and vision statements reveals how promotional linguistic practices can influence the ways international companies develop mission statements. The goal of this study is to, therefore, use the transitivity theory to examine the experiential processes used to enact the promotional rhetoric in the mission and vision statements of the international corporate companies.

\section{Theoretical framework}

Genre studies use a variety of frameworks to analyse a range of textual artefacts that are developed and used by disciplinary members (Bhatia, 2004; Swales, 1990). This research drew on genre analysis in particular to answer the research questions that revolved around the construction of a certain text type as a distinctive genre in specified professional discourse communities. Promotional discourse refers to a constellation of closely related genres with overlapping communicative purposes that include promoting products or services to potential customers such as advertisements, promotional letters and book blurbs (Bhatia, 2004). While some may not exactly appear as ads, however, Bhatia (2004) stated that their rhetorical moves 
show promotional concerns. Moreover, sometimes the promotional text may not be about promoting product or service, but an idea. Mission and vision statements are becoming increasingly creative as they use rhetorical moves and lexico-grammatical structure that instigate a high degree of reader attraction. Sometimes, the purpose of these texts can be identified as introducing business proposition per se. Most popular promotional strategies are based on the rhetoric of description and evaluation of products or services by using positive evaluative lexico-grammatical forms. These genres that possess informative and commercial purposes have been defined as mixed genres and are known as 'info commercial'.

As stated earlier, mission-writing has similar rhetorical moves to Bhatia's (2004) model of promotional genre (see table-1). This rhetoric is evident in how mission statements are characteristically lengthy and captivating. For this purpose, we used Bhatia's (2004) rhetorical moves of promotional genre to examine mission statements of international companies. In light of Bhatia's (2004) theory, a study of language use in the world of professional culture would be required to understand the complex realities of discursive performances. This analysis requires the genre analyst to examine the surface-level linguistic properties of the text type. This gives significance to the lexico-grammatical forms that make up the text. Thus, the focus of this space is not primarily the context, but the co-text (Bhatia, 2004). Textual space deals with the knowledge of language structures and corresponding functions that are employed to construct the text in typified situations. The emphasis is, therefore, on properties linked to the construction of textual space. For this purpose, we identified transitivity patterns of grammar, which were used as linguistic resources to establish experiential meanings. We analysed those rhetorical moves by textually identifying the experiential processes through which texts are constructed in accordance with SFL.

Table-1: The model offered by Bhatia

\begin{tabular}{|l|l|}
\hline Move 1 & Headlines \\
\hline Move 2 & Targeting the Market \\
\hline Move 3 & $\begin{array}{l}\text { Justifying the product or service } \\
\text { Step 1: by indicating the importance or need of the product or service } \\
\text { Step 2: by establishing a niche }\end{array}$ \\
\hline Move 4 & $\begin{array}{l}\text { Detailing the product or service } \\
\text { Step1: identifying the product or service } \\
\text { Step 2: describing the product or service } \\
\text { Step 3: indicating the value of the product or service }\end{array}$ \\
\hline Move 5 & Establishing credentials \\
\hline Move 6 & Celebrity or typical user endorsement \\
\hline Move 7 & Offering incentives \\
\hline Move 8 & Using pressure tactics \\
\hline Move 9 & Soliciting response \\
\hline
\end{tabular}

Source: Bhatia (2004, p. 74)

The current study focuses on exploring the rhetorical moves that help in producing the mission and vision statements of a company; hence, the grammar of clause as representation complimented the analysis. This grammatical choice is known as the transitivity patterns; it defines the experiential meanings of the world; of perception; of experiences and the reaction. By exploring the transitivity patterns in the texts of the mission and vision statements, we can 
explain how the communicative event is being constructed; we can thus decipher what is being talked about. The clauses are generally encoded in the process types (material, mental, behavioural, verbal, existential, relational) which specify the action, relationship between the participants and events, and where the processes are situated circumstantially (for time, place, cause, etc.).

\subsection{Transitivity analysis}

Because the textualization of genre involves studying the lexico-grammatical features, SFL was followed by studying the transitivity patterns of experiential processes. Transitivity analysis offers a detailed description of the construction of clauses and the functions they perform; it offers an understanding of how meanings are encoded in experiential processes. By examining the transitivity patterns in text, we explained how the field of situation is being constructed, i.e., we described 'what is being talked about' and 'how shifts in the field' are achieved. Transitivity patterns of experiential meanings comprise: (i) material process which describe processes as doing, usually of concrete and tangible actions, "some entity does something, undertakes some action" (Eggins, 2004, p. 243); (ii) mental processes which define what we feel or talk about; they are clauses which encode processes of feeling or thinking; (iii) behavioural processes which encode processes of behaviour. The one who executes the behaviour is defined as 'doer' and the type of behaviour that is executed is defined as 'circumstance'; (iv) verbal process which contains three participants: Sayer, Receiver and Verbiage. The Verbiage is a nominalized statement of the verbal process: a noun expressing some kind of verbal behaviour; (v) relational processes, which encode meanings about state of being, are categorized in two types: attributive and identifying processes. Attributive process involves establishing a relationship between two processes. In the attributive process type, a quality or attribute - defined as the carrier - is assigned to the participant. Identifying processes are different from attributive in that the identifying clause is not about attributing or ascribing but defining. What can further differentiate between identifying and attributive processes is that the nominal group in attributive is an indefinite nominal group such as 'a healthy fruit' whereas the identifying process involves a definite nominal group such as 'the healthy fruit'; (vi) Causative relational occur with either Attributive or Identifying structures. The causation process is expressed either through a make + be (Process: intensive) structure, or, with Identifying Relational, through a causative process.

The purpose of using SFL theory as a method of analysis is to reveal how promotional rhetoric is enacted. For this purpose, we have analysed each rhetorical move's linguistic properties and lexico-grammatical structures. By identifying the typical lexico-grammatical structures, we were able to define how a certain rhetorical move is validated.

\section{Research methodology}

The purpose of this research was to explore and present the generic patterns of writing mission and vision statements by analysing the lexico-grammatical structures. Therefore, the methodology for genre analysis included qualitative research method. The qualitative research method relied on descriptive data with little emphasis given to numerical quantification (Jason \& Glenwick, 2016). Because mission and vision statements are real texts that are socially constructed, and the meanings derived from such texts rely on the specific context of interaction; using qualitative research method allowed carrying an in-depth examination of the generic patterns of mission and vision statements. 
This research has followed a descriptive method to analyse mission and vision statements of international corporate companies. A manual lexico-grammatical analysis of promotional rhetorical moves was carried out to identify the experiential processes used to enact the rhetorical moves. Purposive sampling was used, which is also known as deliberate sampling that involves "purposive or deliberate selection of particular units of the universe for constituting a sample which represents the universe" (Kothari, 2004, p. 15). Following purposive sampling, hundred international companies were selected from the list provided by Forbes Global ${ }^{1}$ which provides an annual ranking list of top 2000 companies' ranking based on four metrics: sales, profit, assets and market value The technique of purposive sampling allowed us pick and choose the data according to a set criterion of requirements (Etikanet al., 2015). It means that the data used for this study was deliberately chosen based on some required qualities/characteristics. The criterion for selecting sentence examples from the mission and vision statements is that they reflect any of the rhetorical moves of promotional genre such as 'targeting the market' or 'establishing niche'.

First, the rhetorical moves of the selected mission and vision statements were manually explored using Bhatia's (2004) model of promotional genre. An inter-coder reliability method was followed to assess the moves formally, and the obtained percent of the agreement was $88.5 \%$. The model was then used to analyse the grammatical clause structure of the rhetorical moves existing in the data. Rhetorical moves of promotional genre were analysed to examine their lexico-grammatical structures.

Using transitivity analysis (Eggins, 2004), the clause structure of the moves was identified. Then, the experiential processes employed to structure the clauses were examined. For instance, mental process wasused to enact move three i.e., 'justifying the product or service'. Mental process as a lexico-grammatical structure was best suited for this particular rhetorical move as it fulfilled the function of persuading the targeted audience that they have a problem and that the service or product of the company is the best solution.

Following this method of analysis, transitivity pattern of experiential processes was quantified by counting the occurrences of each experiential process in every rhetorical move. Using this method, the results revealed the most typical transitivity pattern used to enact the promotional rhetorical move. First, results were quantified by presenting percentage of occurrence in tabulation form. Then, each experiential process was explained by identifying its prototypical move. Analysis of the grammatical clause was provided as an example, followed by a number of other listed instances fetched from the data. Each experiential process was defined and explained as to how and why one type was more common than the other in a certain rhetorical move.

The data gathered for this study was publicly displayed on the official websites of international corporate companies. No company was privately emailed to provide their mission and vision statements. The official web link of the selected mission and vision statement mentioned in the footnote can be publicly accessed.

\section{Results and discussion}

We first considered the range of transitivity patterns and their use with each rhetorical move, giving special emphasis to the most frequent experiential process occurring with each rhetorical move. Figure 1 shows the overall distribution of experiential processes. 
Figure 1: Use of experiential processes across promotional moves

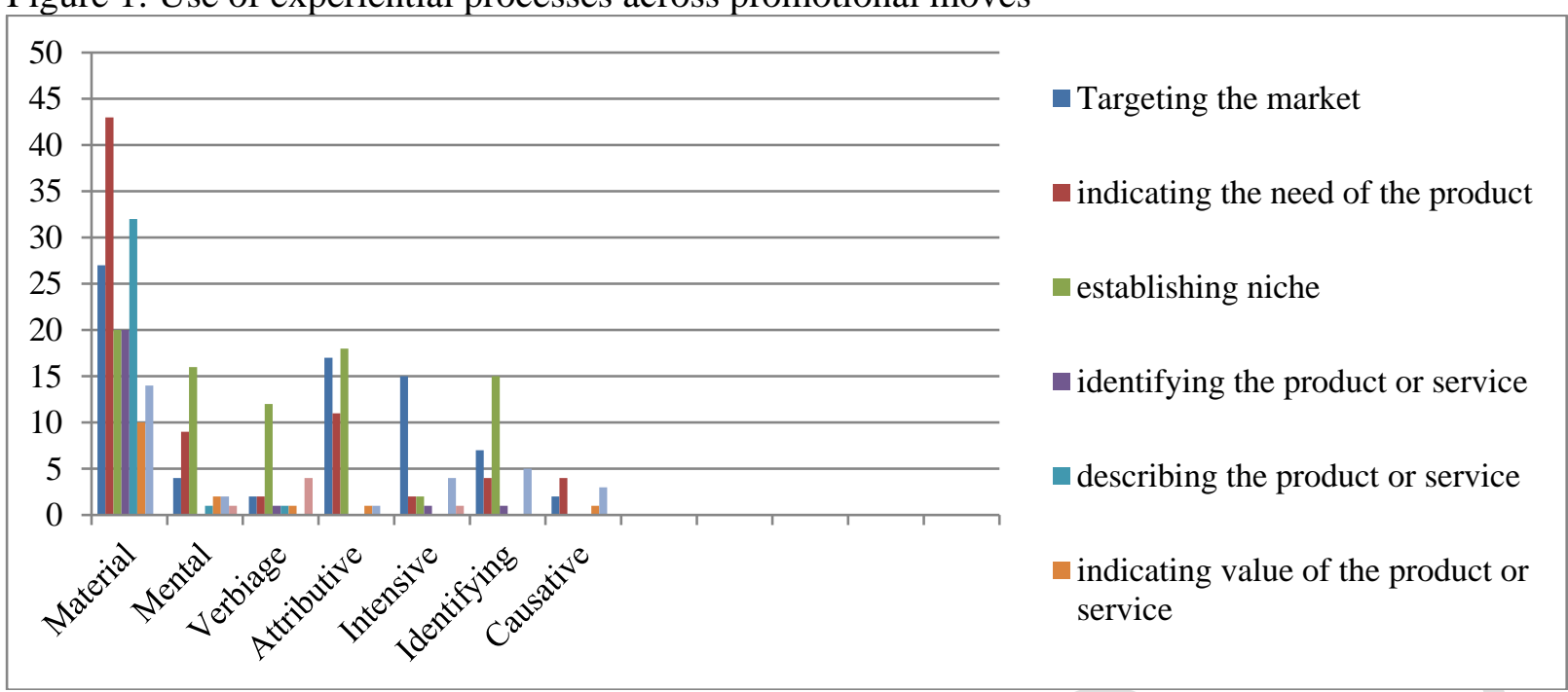

The analysis of rhetorical moves of international corporate companies from SFL perspective revealed significant results about the role of experiential processes used when writing mission statement. The study found that mission writing relies heavily on material process to enact most of the rhetorical moves. This could be due to the communicative purpose of writing mission statements. Generally, corporate companies wish to inform their customers about what they do and what their services or products are, which requires them to use concrete tangible clauses. The percentage of material process was $16.2 \%$ in $\mathrm{M} 2,25.9 \%$ in $\mathrm{M} 3 \mathrm{~S} 1,12.04 \%$ in $\mathrm{M} 3 \mathrm{~S} 2$, $12.04 \%$ in M4S1, $19.2 \%$ in M4S2, $6.02 \%$ in M4S3 and 8.4\% in M5.

The analysis revealed that material processes were mostly used to enact M4 i.e., 'describing the product or service'. Arguably, international corporate companies employ this move to inform the targeted audience about their services and products. This finding was also reported by Yurtseven (2003) who found that $52 \%$ of these mission statements focus on product and service promotion. Arguably, part of developing public image and establishing self-concept requires the professional community to integrate their plans, define products and service and indicate the value of the services or products. Moreover, material process was also frequently used with M3S1i.e. 'indicating the importance of the service'.

The percentage of mental process was $11.4 \%$ in $\mathrm{M} 2,25.7 \%$ in $\mathrm{M} 3 \mathrm{~S} 1,45.7 \%$ in M3S2. The analysis revealed that mental process was mostly used to enact M3S2 which is 'establishing niche'. The percentage of attributive process was $35.4 \%$ in $\mathrm{M} 2,22.9 \%$ in $\mathrm{M} 3 \mathrm{~S} 1,37.5 \%$ in M3S2. The analysis revealed that attributive process was mostly used to enact M3S2 which is 'establishing niche' and M2 which is 'targeting the market'. The percentage of intensive process was $60 \%$ in M2 and 16\% in M5 which is 'establishing credentials.' The analysis revealed that intensive process was mostly used to enact M3S2i.e. 'establishing niche'. These results indicate that the selected hundred international corporate firms use mission statements as a distinctive text type primarily to reinforce their position in the market via the rendition of a positive image. Similar findings were established by Lin et al. (2018) who stressed on the significance of mission statements as they tend to connect international stakeholders and portray global careers and international competition.

The percentage of identifying process was $21.8 \%$ in $\mathrm{M} 2,12.5 \%$ in M3S1, $46.8 \%$ in M3S2 and 
$15.6 \%$ in M5 which is 'establishing credentials. The analysis revealed that identifying process was mostly used to enact M3S2 i.e., 'establishing niche' significantly denoting that international companies rely on establishing a positive public image as a means to promote their presence within the established market. When a larger number of companies focus on 'targeting the market', it indicates that they generally strive for recognition in a market of competition. This finding was also evident in Koller's study (2009), which concluded that mission statements were considered as ideally suited to act as branding propositions to various audiences. Furthermore, a market-oriented communication is generally understood as the type of communication in which the company reinforces itself through positive image (Christensen \& Askegaard, 2001).

The percentage of verbiage process was $52.1 \%$ in M3S2 and $17.3 \%$ in M6. The analysis revealed that verbiage process was mostly used to enact M3S2and M6, which are 'establishing niche' and 'celebrity endorsement' respectively. As defined by Campbell et al. (1991), mission statements are used by companies to build a public image while defining their philosophies and values. This definition seems to be the reason for which mission statements rely on Relational Identifying Process $72 \%$ to 'establish niche' as a means for building public image. Attributive process was also found to be recurrently used to 'target the market' used by the professional community to specify their position by defining their attributes.

Table-2: Percentage of occurrence of experiential processes across promotional moves

\begin{tabular}{|l|l|l|l|l|l|l|l|}
\hline Description & MAT & MENT & VERBI & ATTR & INT & IDE & CAUS \\
\hline Targeting the market & $16.20 \%$ & $11.40 \%$ & $4.34 \%$ & $35.40 \%$ & $60 \%$ & $21.80 \%$ & $20 \%$ \\
\hline $\begin{array}{l}\text { Indicating the need of the } \\
\text { product }\end{array}$ & $25.90 \%$ & $25.70 \%$ & $8.69 \%$ & $22.90 \%$ & $8 \%$ & 12.5 & $40 \%$ \\
\hline Establishing niche & $12.04 \%$ & $45.70 \%$ & $52.17 \%$ & 37.5 & $8 \%$ & $26.80 \%$ & $0.00 \%$ \\
\hline $\begin{array}{l}\text { Identifying the product or } \\
\text { service }\end{array}$ & $12.04 \%$ & 0.00 & $4.34 \%$ & $0.00 \%$ & $4 \%$ & 3.12 & $0.00 \%$ \\
\hline $\begin{array}{l}\text { Describing the product or } \\
\text { service }\end{array}$ & $19.20 \%$ & $2.85 \%$ & $4.34 \%$ & $0.00 \%$ & $0.00 \%$ & $0.00 \%$ & $0.00 \%$ \\
\hline $\begin{array}{l}\text { Indicating value of the } \\
\text { product or service }\end{array}$ & $6.02 \%$ & $5.71 \%$ & $4.34 \%$ & $4.34 \%$ & $0.00 \%$ & $0.00 \%$ & $10 \%$ \\
\hline Establishing credentials & $8.43 \%$ & $5.71 \%$ & $0.00 \%$ & $2.08 \%$ & $16 \%$ & $15.60 \%$ & $30 \%$ \\
\hline Celebrity endorsement & $0.00 \%$ & $2.85 \%$ & $17.30 \%$ & $0.00 \%$ & $4 \%$ & $0.00 \%$ & $0.00 \%$ \\
\hline
\end{tabular}

In accordance with prior research, the present results have demonstrated similar findings. Stated that mission statements are becoming a prototypical example of branding and marketization, the analysis of lexico-grammatical structures corroborates this stance. As seen in Table 1, international companies heavily rely on attributive processes to describe their qualities as idiosyncratic and innovative. Similarly, international companies also focus on describing products and services, by using material processes to reflect their actions as concrete and tangible. It can, therefore, be argued that the analysis of mission statements from an SFL perspective revealed that this text type carries greater similarities to promotional genre.

\subsection{Material process}

This process was typically most frequent in M4 i.e., 'detailing the product or service'. Material 
process as a lexico-grammatical structure was best suited for this particular rhetorical move as it fulfilled the function of 'identifying the service or product' which required the companies to define it as a tangible, concrete and action-oriented practice. Material verbs such as provide, use, craft, produce, discover, give and offer identify the service or product that a certain company wants their customers to learn about. Examples of 'detailing the product or service' as a rhetorical move using material processes included:

- We provide quality, reliable and environmentally friendly energy

- Crafting great beer from the best natural ingredients

- Provide competitive high quality electronics manufacturing services

- Produce world class professionals

- Discover, develop and commercialize innovative therapeutics

- Deliver breath-taking innovations

- Giving our customers a unique competitive edge

- Deliver unmatched joyful vacations for our guests

Table-3: Transitivity pattern in material process

\begin{tabular}{llll}
\hline Actor & Process (material) & Goal & Beneficiary \\
\hline We & Provide & environmentally friendly energy & for our guests \\
& Craft & quality electronics & \\
& $\begin{array}{l}\text { Produce } \\
\text { deliver }\end{array}$ & joyful vacations & \\
& & & \\
\hline
\end{tabular}

\subsection{Mental process}

Mental process was used to enact M3 i.e., 'justifying the product or service'. Mental process as a lexico-grammatical structure was best suited for this particular rhetorical move as it fulfilled the function of persuading the targeted audience that they have a problem or need some assistance and that the service or product of the company is the best solution. This purpose can be best achieved by manipulating people's thoughts, emotions, and perceptions about a certain idea or entity using verbs denoting mental process. Examples of mental verbs such as strive, aware, see, imagine, aim, value and believe help persuade people to feel, think, or believe in a certain service or product. Examples of 'justifying the product or service' using mental process included:

- We are fully aware that we are a global enterprise

- See this nation emerge as a competition

- The way we see it, the impossible is not impossible

- Never satisfied with the status quo, we imagine what's next

- At Boeing, they value diversity because it is important

- We believe in taking responsibility

- We believe that good business means a better world

Table-4: Transitivity pattern in mental process

\begin{tabular}{|l|l|l|l|}
\hline Senser & Process (mental) & Phenomenon act & Phenomenon fact \\
\hline $\mathrm{We}$ & Aware & What's next \\
$\mathrm{We}$ & Diversity & $\begin{array}{l}\text { that we are a global } \\
\text { enterprise }\end{array}$ \\
\hline
\end{tabular}




\subsection{Relational processes}

\subsubsection{Relational attributive process}

This process was used in M3S2 i.e., 'establishing niche'. Attributive process as a lexicogrammatical structure was a prototypical structure for this particular rhetorical move to fulfil the function of identifying institute's beliefs and values. Companies define their public image through attribution and by identifying their beliefs and values to justify the service or product reflected in their mission and vision statements. Company's firm beliefs, values, and aspirations are realised through attributive nouns and adjectives that reflect company's selfconcept. This purpose was best achieved by using attributive or identifying lexico-grammatical structures. Examples are given to show how employing attributive and identifying structures help establish the niche and self-concept of companies as a means of distinguishing themselves from others.

- Bizzard Entertainment is what it is today

- Takuda is a patent focused, innovation-driven global pharma company

- Everyone here is a geek at heart

- We are leaders in progress

- It is a sense of inspiration and mobility

Table-5: Transitivity pattern in attributive process

\begin{tabular}{lll}
\hline Carrier & $\begin{array}{l}\text { Process } \\
\text { (attributive) }\end{array}$ & Attribute \\
\hline $\begin{array}{l}\text { Bizzard entertainment } \\
\text { Takuda }\end{array}$ & Is & what it is today \\
Everyone & & patent focused \\
\end{tabular}

Attributive process was also predominantly used to enact M2i.e. 'targeting the market'. The typical lexico-grammatical structure denoting this move was to use attributive process 'to be a' or intensive attributive 'to be the' followed by the attribute. Using this particular lexicogrammatical structure was fundamental to achieve this rhetorical move which requires companies to define their geographic allocation and role within the market they plan to be a part of Typical lexico-grammatical structures to enact 'targeting the market' as a rhetorical move were: to be the leading company, leading institute, world's leading, and world's best.

- To be a leading, competitive, Nutrition, Health and Wellness Company

- Our vision is to be earth's most customer-centric company

- Our Vision is to be the world's pre-eminent life insurance provider

- To be the most respected Internet enterprise

- Be a role model for contribution to society

Table-6: Transitivity pattern in attributive process

\begin{tabular}{lll}
\hline Carrier & $\begin{array}{l}\text { Process } \\
\text { (attributive) }\end{array}$ & Attribute \\
\hline Our vision & To be & A leading \\
& & A role model \\
\hline
\end{tabular}




\subsubsection{Relational identifying process}

This move was typically realized in M5i.e. 'establishing credentials'. The most common lexico-grammatical features characteristically identifiable with M5 were largely dependent on relational intensive process (be+the+attribute) such as world's leading, is the major company, and is the top. Above intensive processes, it is largely depended on circumstantial process by relying on dates, years and numbers such as: adopted June 10, more than 100 years, two billion a day, in 2009, since 1954, and built over 150 years ago.

- Nestlé is......the world's leading nutrition, health and wellness company

- Customer reviews, 1-Click shopping, personalized recommendations, Prime, Fulfilment by Amazon, AWS, Kindle Direct Publishing, Kindle, Fire tablets, Fire TV, Amazon Echo, and Alexa are some of the products and services pioneered by Amazon

- The following principles guide our relationship with our stakeholders

- Two billion times a day, P\&G brands touch the lives of people around the world

- From carbon abatement to disaster recovery to bringing tech education to underfunded schools, we've made some tremendous progress so far.

- AT\&T has recorded 35 consecutive years of quarterly dividend growth and is a Fortune 10 company.

- After careful formulation and thorough discussion, the Board approved the Group's Vision, Mission and Core Values (VMV), the bedrock of our corporate culture, in 2004. With this initiative, we have embarked on building a coherent and bank-wide corporate culture and spirit that will motivate us and move us forward in the 21 st century.

Table 7: Transitivity pattern in relational identifying process

\begin{tabular}{llll}
\hline Token & $\begin{array}{l}\text { Process } \\
\text { (identifying) }\end{array}$ & Value & Circumstance \\
\hline Nestlé & Is & $\begin{array}{l}\text { the world's leading } \\
\text { nutrition, health and } \\
\text { wellness company billion times a day }\end{array}$ & $\begin{array}{l}\text { Twe bedrock of our } \\
\text { corporate culture, in }\end{array}$ \\
$\begin{array}{l}\text { Customer reviews, } \\
\text { 1-Click shopping }\end{array}$ & Are & $\begin{array}{l}\text { some of the products } 2004 \\
\text { and services pioneered } \\
\text { by Amazon } \\
\text { our relation }\end{array}$ \\
following principles & Guide & & \\
\hline
\end{tabular}

\subsection{Verbal process}

This process was typically used in M6 i.e., 'celebrity or typical user endorsement'. Verbal process as a lexico-grammatical process was best suited for this particular rhetorical move to fulfil the function of affiliating a company's name with other renowned companies or eminent philosophers by quoting their statements for the purpose of endorsement. This purpose was best achieved through direct or indirect quotations through lexico-grammatical structure that include a verbiage and a verbal process. Typical phrases are currently used with move six are: Gilman Said, Reed Hastings says, said Jeff Silverman.

- In October 2011, co-founder and CEO Reed Hastings expressed a clear vision for the future of Netflix: "We cannot close our eyes to the challenges that the world faces. Business must make an explicit and positive contribution to addressing them. I'm 
convinced we can create a more equitable and sustainable world for all of us by doing so," says Unilever's former CEO Paul Polman. "But this means that business has to change. The Unilever Sustainable Plan is a blueprint for sustainable growth."

- We frequently partner with leading industries, and support and facilitate entrepreneurship among our students and faculty

- "My heart is in the work."

- Andrew Carnegie

- "It takes the same amount of energy to dream big as it does to dream small." CarlosBrito CEO of AB InBev

Table 8: Transitivity pattern in verbal process

\begin{tabular}{lll}
\hline Sayer & $\begin{array}{l}\text { Process } \\
\text { (verbal) }\end{array}$ & Verbiage \\
\hline $\begin{array}{l}\text { Unilever's former CEO Paul } \\
\text { Polman }\end{array}$ & says & $\begin{array}{l}\text { I'm convinced we can create a } \\
\text { more equitable and sustainable } \\
\text { world for all of us by doing so }\end{array}$ \\
Carlos BritoCEO of AB InBev & $\begin{array}{l}\text { It takes the same amount of } \\
\text { energy to dream big as it does } \\
\text { to dream small }\end{array}$ \\
\hline
\end{tabular}

\subsection{Causative process}

This process was typically frequent in M3S1i.e. 'referring to its need for growth and survival'. Causative process as a lexico-grammatical process was best suited for this particular rhetorical move as it fulfilled its function of persuading the audience or customers that they have a problem and that their problem can be solved by causing change to occur. Typical phrases recurrently used to enact this step are: make a difference, make life better, and make the world a better place.

- Make a difference in the lives of people

- We innovate to make the world a healthier place

- To make everyday life just a little bit better

Table 9: Transitivity pattern in causative process

\begin{tabular}{ll}
\hline $\begin{array}{l}\text { Process } \\
\text { (causative) }\end{array}$ & Circumstance \\
\hline Make & $\begin{array}{l}\text { A difference } \\
\text { the world a healthier place } \\
\text { everyday life }\end{array}$ \\
\hline
\end{tabular}

\section{Conclusion}

The purpose of this study was to examine how mission and vision statements of international corporate companies were rhetorically organised and to identify the transitivity patterns used for writing mission and vision statements. The data comprised hundred mission and vision statements of international corporate companies fetched from Global Forbes which provides an annual ranking list of top 2000 companies' ranking based on four metrics: sales, profit, assets and market value. Two theoretical frameworks informed this research: (i) promotional 
genre, and (ii) systemic functional linguistics. A move analysis was followed using Bhatia's (2004) proposed methodology for genre analysis. Then, transitivity patterns of moves' clausal structures were analysed.

The purpose of this research was to explore how promotional rhetoric is enacted through experiential processes. To understand the communicative purposes achieved through lexicogrammatical features, this research revealed the most frequent experiential processes associated with each rhetorical move of mission and vision statements. The interplay of rhetorical moves and their surface-level grammatical structures has provided a more meaningful description on the use of specific lexico-grammatical resources and how they develop meanings.

To recapitulate, transitivity patterns of experiential meanings in examples of mission and vision statements display the rhetorical moves employed by companies to position their public image, showcase who they are, and state what they intend to do. To construct a public image, companies rely on 'establishing niche' as a rhetorical move, which was predominantly conveyed through attributive and identifying processes. This may be considered as a further validation of Bhatia's (2004) idea of typical promotion. A further novel conclusion is that companies also try to 'target the market' because of the increasing competition between companies. This may be considered as a new contribution to the genre of mission statements, where companies can define their targeted customers by making their mission statements market oriented.

Essentially, writing mission and vision statements is part of the management and planning of an institute or company. The influence of policy guidelines and planning has certainly strengthened the establishment and practice of writing mission and vision statements to fulfil a number of communicative purposes. First, a mission statement orients the company to the needs of its community which includes the macro and micro communities. Second, having an ideal mission statement reflects the quality performance of an organisation by facilitating its employees, staff members, methodology and practices within the professional setting. The main conclusion that can be drawn is that writing mission statements is a prerequisite of policy guidelines offered by companies. However, promotional genre has become a practiced culture in this professional setting where companies constantly strive to build their public image as innovative and idiosyncratic.

Because companies aim to establish their social role in the corporate discourse community, they largely focus on promotional agendas. This requires them to write mission statements that define their nature, beliefs, and values. Using SFL theory, we conclude that mental and relational processes are favoured linguistic practices used by international companies to write mission statements that focus on building public image.

The positionality of rhetorical elements realised through certain types of experiential processes has helped in establishing a correlation between linguistic resources and their established communicative values within this genre. This analysis can be extended to inform research on other professional discourse communities. To gain a deep insight of this genre, research needs to be done into other discourse communities that use a similar genre. The analysis conducted in this research has generated deep understanding into how this genre is rhetorically organized and how the process of producing unique and idiosyncratic mission statements is negotiated through lexico-grammatical features. This analysis can also be applied to study 'About Us' section of companies' websites which are still under exploration. For instance, this model can 
be used to examine their clause structures and how they conform to promotional rhetoric. The findings provide potential mechanism for the mission statements to be defined as a subcategory of the promotional genre. Using the SFL theory as lens to analyse the promotional rhetoric in mission statements, it can be argued that transitivity patterns of experiential processes may be considered as a promising theory to analyse the mission statements of other discourse communities.

\section{References}

Allison, J. (2017). Advancing strategic communication through mission statements: Creation of a natural language taxonomy. Academy of Strategic Management Journal, 16(3), $1-9$.

Ahmad, N. N. \& Masroor, F. (2020). The study of generic patterns of mission and vision statements of the universities. Liberal Arts and Social Sciences International Journal (LASSIJ), 4(2), 159-178. https://doi.org/10.47264/idea.lassij/4.2.13

Askehave, I. (2007). The impact of marketization on higher education genres - the international student prospectus as a case in point. Discourse Studies, 9(6), 723-742. https://doi.org/10.1177/1461445607082576

Bartkus, B., Glassman, M., \& McAfee, B. (2006). Mission statement quality and financial performance. European Management Journal, 24(1), 86-94. https://doi:10.1016/j.emj.2005.12.010

Bateman, J. (2008). Multimodality and genre: A foundation for the systematic analysis of multimodal documents. Palgrave MacMillan.

Benelhadj, F. (2019). Discipline and genre in academic discourse: Prepositional phrases as a focus. Journal of Pragmatics, 139, 190-199. https://doi.or/10.1016/j.pragma.2018.07.010

Bhatia, V.K. (1983). An applied discourse analysis of English legislative writing. The University of Aston Language Studies Unit.

Bhatia, V. K. (2004). Worlds of written discourse: A genre-based view. A\&C Black.

Bittencourt, T., \& Willetts, A. (2018). Negotiating the tensions: A critical study of international schools' mission statements. Globalisation, Societies and Education, 16(4), 515-525. doi:10.1080/14767724.2018.1512047

Boerema, A. J. (2006). An analysis of private school missions statements. Peabody Journal of Education, 81(1), 180-202. https://doi.org/10.1207/S15327930pje8101_8

Breznik, K., \& Law, K. M. (2019). What do mission statements reveal about the values of top universities in the world? International Journal of Organizational Analysis, 27(5), 1362-1375.https://doi.org/10.1108/IJOA-08-2018-1522

Campbell, A., Devine, M. and Yeung, D. (1991). A sense of mission. Pitman Publishing.

Christensen, L. T., \& Askegaard, S. (2001). Corporate identity and corporate image revisited: A semiotic perspective. European Journal of Marketing 35 (3-4), 292-315. https://doi.org/10.1108/03090560110381814

David, F., Ali, A., \& Al-Aali, A. (2011). Strategic management: Concepts and cases. Education Ltd.

David, M.E., \& David, F.R. (2014). Mission statement theory and practice: A content analysis and new direction. International Journal of Business, Marketing and Decision Sciences, $7(1)$,

95-110. http://citeseerx.ist.psu.edu/viewdoc/download?doi=10.1.1.1038.1592\&rep=rep1\&ty $\underline{\text { pe }=\mathrm{pdf}}$ 
Derewianka, B. (1990). Exploring how texts work. Primary English Teaching Association. Drucker, P. (1974). Management: Tasks, responsibilities, and practices. Harper \& Row. Eggins, S. (2004). Introduction to systemic functional linguistics ( $2^{\text {nd }}$ ed.). A \& C Black.

Etikan, I., Musa, S. A., \& Alkassim, R. S. (2015). Comparison of convenience sampling and purposive sampling. American Journal of Theoretical and Applied Statistics, 5(1), 14.

Fairclough, N. (1993). Critical discourse analysis and the marketization of public discourses: The universities. Discourse \& Society 4(2), 133-168. https://doi.org/10.1177/0957926593004002002

Gleason, J. (2014). Meaning-based scoring: A systemic functional linguistics model for automated test tasks. Hispania, 97(4),

666-688. https://doi.org/10.1353/hpn.2014.0115

Goertzen, P., \&Kristjánsson, C. (2007). Interpersonal dimensions of community in graduate online learning: Exploring social presence through the lens of systemic functional linguistics. The Internet and Higher Education, 10(3), 212-230. https://doi.org/10.1016/j.iheduc.2007.06.005

Hafferty, F. W., Grbic, D., \&Hafferty, P. K. (2019). Mapping the mission statements of U.S. LCME-Accredited medical schools. Academic Medicine, 94(5), 723-730. https://doi.org/10.1097/acm.0000000000002626

Halliday, M. A. K. (1978). Language as social semiotic. Edward Arnold.

Halliday, M.A.K. (1994). An introduction to functional grammar. Edward Arnold.

Halliday, M. A. K., \& Matthiessen, C. M. I. (2004). An introduction to functional grammar. Routledge.

Hasan, R. (2009). The place of context in a systemic functional model. In M.A.K. Halliday and J. Webster (Eds.). Continuum companion to systemic functional linguistics (pp.166189). Continuum.

Hayden, M. J. (2012). Mission statement possible: International schools and cosmopolitanism. The International Education Journal: Comparative Perspectives, 11(2), 5-26. https://openjournals.library.sydney.edu.au/index.php/IEJ/article/view/7111

Holland, J. J., \& Nichele, E. (2016). An ideological content analysis of corporate manifestos: A foundational document approach. Semiotica, 208, 79-101. https://doi.org/10.1515/sem-2015-0115

Hongwei, He. (2012). Corporate identity anchors: A managerial cognition perspective. European Journal of Marketing, 46(5), 609-625.

Jason, L. A. \& Glenwick, D. S. (2016). Handbook of methodological approaches to community-based research: Qualitative, quantitative, and mixed methods. Oxford University.

Kemp, S., \& Dwyer, L. (2003). Mission statements of international airlines: A content analysis. Tourism Management, 24(6), 635-653. $\quad$ https://doi.org/10.1016/S0261$\underline{5177(03) 00049-9}$

Khalifa, A.S. (2011). Three f's for the mission statement: What's next? Journal of Strategy and Management, 4(1), 25-43. https://doi.org/10.1108/17554251111110104

Koller, V. (2009) Corporate self-presentation and self-centredness: A case for cognitive critical discourse analysis. In H. Pishwa (Eds.). Language and social cognition expression of the social mind (p. 267-288). Mouton de Gruyter Berlin.

Kothari, C. R. (2004). Research methodology: Methods \& techniques. New Age International. Li, J. (2010). Transitivity and lexical cohesion: Press representations of a political disaster and its actors. Journal of Pragmatics, 42(12), 3444-3458. https://doi.org/10.1016/j.pragma.2010.04.028 
Lin, Y. H., Ryan, C., Wise, N., \& Low, L. W. (2018). A content analysis of airline mission statements: Changing trends and contemporary components. Tourism Management Perspectives, 28, 156-165. https://doi.org/10.1016/j.tmp.2018.08.005

Martin, J., \& White, P. R. (2007). The language of evaluation: Appraisal in English. Springer.

Martinez, I. A. (2001). Impersonality in the research article as revealed by analysis of the transitivity structure. English for Specific Purposes, 20(3), 227-247. https://doi.org/10.1016/s0889-4906(00)00013-2

Mason, M. \& Mason, R.D. (2012). Communicating a green corporate perspective: Ideological persuasion in the corporate environmental report. Journal of Business and Technical Communication, 26(4), 479-506. https://doi.org/10.1177\%2F1050651912448872

Ozdem, G. (2011). An Analysis of the mission and vision statements on the strategic plans of higher education institutions. Educational Sciences: Theory \& Practice, 11(4), 18871893.https://eric.ed.gov/?id=EJ962679

Pearce, J. A., \& David, F. (1987). Corporate mission statements: The bottom line. Academy of Management Perspectives, 1(2),

109-115. https://doi.org/10.5465/ame.1987.4275821

Pho, P. D. (2008) Research article abstracts in applied linguistics and educational technology: A study of linguistic realizations of rhetorical structure and authorial stance. Discourse Studies 10(2): 231-250. https://doi.org/10.1177\%2F1461445607087010

Ravelli, L. (2000). Getting started with functional analysis of texts. In Len Unsworth (Ed.). Researching language in schools and communities: Functional linguistic perspectives (pp. 27-64). Cassell\& Co.

Rego, A., Araújo, B., \& Serrão, D. (2015). The mission, vision and values in hospital management. Journal of Hospital Administration, 5(1). https://doi.org/10.5430/jha.v5n1p62

Rozycki, E.G. (2004). Mission and vision in education. Educational Horizons, 82(2), 94-98.

Swales, J. (1990) Genre analysis: English in academic and research settings. Cambridge University.

Swales, J. M., \& Rogers, P. S. (1995). Discourse and the projection of corporate culture: The mission statement. Discourse and Society, 6(2), 223-242. https://doi.org/10.1177/0957926595006002005

Thompson, G. (2000) Introducing functional grammar. Edward Arnold.

Vathanalaoha, K., \& Tangkiengsirisin, S. (2018). Genre analysis of experiment-based dental research article abstracts: Thai and international journals. $3 L$ The Southeast Asian Journal of English Language Studies, 24(3), 1-14. https://doi.org/10.17576/31-20182403-0

Velcoff, J., \& Ferrari, J. (2006). Perceptions of university mission statement by senior administrators: Relating to faculty engagement. Christian Higher Education, 5(4), 329-339. https://doi.org/10.1080/15363750500408090

\section{Notes:}

${ }^{1}$ Forbes (2019, May 2019). Global 2000: The world's largest public companies. Forbes.com. 